\title{
Multiple frames of success: how second-generation immigrants experience educational support and belonging in higher education
}

\author{
Julia Orupabo $^{1}$ (D) Ida Drange ${ }^{2} \cdot$ Bente Abrahamsen $^{3}$
}

Published online: 25 October 2019

(C) The Author(s) 2019

\begin{abstract}
This article explores the impact of cultural resources on success and aspirations among secondgeneration immigrants in higher education in Norway. We investigate whether and how cultural resources are converted into advantages in higher education. The data consist of cross-sectional survey data and in-depth interviews with Norwegian students of immigrant origin. The quantitative analysis challenges the assumption that minority students receive extra support and encouragement from their social environment to guide them through higher education. However, regarding identity, cultural resources may provide a buffer from the exclusion and risks scholars have described as common among non-immigrant working-class students in higher education. We specify how culture works through two different frames of interpreting educational achievement: (1) a dual frame of reference, i.e. comparing their achievements with the poorer conditions in their parents' home countries fosters optimism and (2) a single frame of reference, i.e. comparing their achievements with their peers with ethnic majority background in Norway fosters pessimism. Yet, both frames generate high educational commitment. Whilst the first enables the students to view their place in higher education as almost given, the second enables the students to work harder in order to prove themselves and combat under-expectations.
\end{abstract}

Keywords Cultural resources $\cdot$ Second generation $\cdot$ Educational success $\cdot$ Higher education

\section{Introduction}

In a European context, several comparative studies illustrate that the extent to which secondgeneration non-Western immigrants complete higher education and succeed in the labour

Julia Orupabo

jor@ socialresearch.no

1 Institute for Social Research, P.O. Box 3233, Elisenberg, 0208 Oslo, Norway

2 Work Research Institute, Oslo Metropolitan University, Oslo, Norway

3 Center for the Studies of Professions, Oslo Metropolitan University, Oslo, Norway 
market varies considerably between countries (Heath et al. 2008; Crul et al. 2012). In Norway, second-generation immigrants have conspicuously high participation rates in higher education, even in prestigious 'elite' forms, such as professional education (Støren 2009). This seems remarkable, especially given the lower social class origins of many minority youth. Usually, lower social class origins correlate with lower participation in tertiary education, but this does not seem to apply to ethnic minority students. To explain this 'immigrant paradox', one alternative hypothesis is that these communities draw on cultural resources that promote certain behaviours, values and attitudes regarding higher education (Basit 2012). Education is a crucial component of immigrant families' upward mobility strategies, and the children of immigrants often face high expectations and feel responsible for realising the family's dreams of social ascent (Louie 2012). However, several studies from recent years have argued that what seems like an immigrant paradox is in fact a case of class reproduction (Feliciano and Lanuza 2017). This strand of research emphasises that immigrants' social class in the country of destination poorly reflects their relative and subjective class position in the country of origin and that the second generation's educational behaviour is in continuation with the family's social class origins (Feliciano and Lanuza 2017; Ichou 2014). Departing from this backdrop, we explore how students with working- and middle-class backgrounds experience educational support and how they view their educational trajectories and social mobility.

Most studies investigate the importance of cultural resources for minority students' aspirations in upper secondary school and accessing higher education (Modood 2004; Zhou 2005). Whilst early educational expectations are important predictors of eventual socio-economic attainment, we know relatively little about whether and how cultural resources can continue to function as resources in higher education. Higher education is a middle class arena, in which students with a working-class background are atypical compared with their middle-class peers. Previous studies have described how workingclass students (Lee and Kramer 2013) and students who are 'newcomers' in the middle class (Reay 2008) experience exclusion and feeling 'out of place' in higher education. Thus, an important task is to explore whether children of immigrants receive extra support and encouragement from their social environment to guide them through higher education. In our study, we concentrate on one specific aspect of cultural resources, namely social support from parents, siblings, other extended family members and friends. More precisely, we investigate the extent of support for the choice to purse higher education and, subsequently, how minority ethnic students activate that support to overcome challenges and experiences of exclusion in higher education. In this way, we treat cultural resources as both individuals' valuation of education as a future goal as well as a 'tool kit' of symbols, stories and perspectives they use to interpret their educational choices and manoeuvre in higher education.

Furthermore, this study contributes to the literature by combining interview data and survey data to investigate whether cultural resources in ethnic communities continue to benefit minority students in higher education. Despite the considerable number of empirical studies on the impact of cultural resources, most studies have been qualitative (Modood 2004; Basit 2012). Although these studies find a strong orientation towards education in the abovementioned ethnic communities, few studies have approached this topic using statistical methods to investigate whether the ethnic communities are indeed more supportive of educational activities among their children compared with the parents and peers of majority youth. We base our analysis on a cross-sectional survey among students in higher education and two interview studies conducted among students. 


\section{The Norwegian context}

Norway became a net immigration country in 1967, and immigrants and their children made up 17\% of the Norwegian population in 2017 (Statistics Norway 2017a). Most immigrant subjects in our study derive from the first wave of non-Western immigrants to Norway, which predominantly consisted of immigrants from Turkey, Pakistan, India, Vietnam and Iran. The parental generation has various immigration histories and different social class origins, depending on country of origin. Immigrants from Turkey, Pakistan and India came as labour migrants in the 1970s, and immigrants from Vietnam and Iran came as refugees in the late 1970s and 1980s. There is, of course, within-group variation, but statistically, labour migrants from Turkey had lower social class origins and low education levels, whereas, immigrants from Pakistan and India came from the middle and upper classes, and many had higher education (Tjelmeland 2003). The education level of Indians exceeded that of the majority population (Fekjær 2007). The Vietnamese refugees had low levels of education (Bringsrud 2014), whereas the Iranian refugees, especially women, had high average education levels (Blom and Henriksen 2008). Immigrants are in general, however, overrepresented in the lower social strata in Norwegian society, and there is a significant ethnic wage gap (Statistics Norway $2017 b$ ), which implies that a larger proportion of second-generation immigrants grow up in working-class families compared with the ethnic majority.

The educational achievement and employment outcomes of second-generation immigrants vary between countries. Scholars have argued that institutional factors, such as the interaction between the school system and family resources and support, largely explain these differences. In other words, school systems either do or do not produce early school leavers, and the children of immigrants are among those most affected (Crul et al. 2012). In Norway, secondgeneration immigrants experience strong upward mobility (Hermansen 2016). The Norwegian educational system is characterised by a high degree of inclusiveness, as evidenced by a relatively even standard of education, with a free, centrally regulated secondary and tertiary education system. Furthermore, in contrast to countries that operate with early school tracking, late selection (aged 16) in the Nordic countries gives youth a second chance to move up the educational ladder. Whilst attending vocational education is associated with problems of marginalisation and downward mobility in some European countries (Crul et al. 2012), attending vocational education in Norway can create several different pathways to higher education. Nevertheless, access to higher education in general requires completion of the secondary education level, and research shows that second-generation immigrants, especially boys, are overrepresented among high school dropouts (Støren and Helland 2010).

\section{Class, ethnicity and educational achievement}

The risks and benefits associated with higher education are unequally distributed across social class, and access to higher education remains a more difficult and costly choice for working-class students (Archer and Hutchings 2000). For the majority of working-class young people, not going to university is part of a 'normal biography' (Ball et al. 2002). Different groups make different educational decisions and have different aspirations, even given the same level of achievement (Goldthorpe 2000). To explain such differences, Bourdieu (1984) introduces a sophisticated approach to the study of indirect exclusion by demonstrating how much educational selection occurs through self- 
selection. A key argument is that objective limits (e.g. power and status relationships between groups) become transformed into a subjective sense of one's place in the social world. Such embedded perceptions make certain choices obvious and others unthinkable based on where one stands in the class structure. Hence, educational choices and values can be seen as 'class matching' and a form of social closure (Ball et al. 2002).

Higher education is a middle-class arena, in which students with working-class backgrounds are atypical compared with their middle-class peers. Previous studies have described how working-class students in higher education deal with ambivalence or a 'cleft habitus' (Lee and Kramer 2013). They share the experience of feeling out of place or a 'fish out of water' in higher education (Reay et al. 2001; Archer and Hutchings 2000). Working-class students' experiences in higher education are also described as a process of loss; it is a class journey in which they leave their working-class selves and culture (Jetten et al. 2008). An important insight from this literature is that although individuals with working-class backgrounds enter higher education or middle-class occupations, they may continue to feel 'out of place' in spaces that historically and conceptually are marked as middle class.

However, class identities are not homogeneous. Rather, they intersect with multiple factors, such as gender, race and ethnicity. Previous research claims that social class is less important in explaining educational success and aspirations among the second generation (Modood 2004). Second-generation immigrants experience a strong upward mobility in relation to their parents' generation (Alba and Nee 2003). Scholars have focused on the function of ethnic communities in explaining this paradox (Portes and Rumbaut 2001). These communities provide norms and organisations that promote educational attainment, which also gain members who lack cultural and human capital (Shah et al. 2010). In explaining the apparent pattern of intergenerational mobility, scholars have also focused on an immigrant cultural ethos of hard work and high educational expectations. Basit (2012) shows that immigrant parents of low social origins compensate for their lack of cultural and human capital by providing support and encouragement and by emphasising the value of hard work to their children because these parents believe their children must outperform the majority ethnic group to achieve the same goal. In the literature, this cultural ethos is conceptualised in various ways, such as the 'immigrant advantage' (Portes and Rumbaut 2001) or 'ethnic capital' (Modood 2004). In accordance with this line of reasoning, we would expect immigrant students to report higher levels of encouragement from their family and social environments, especially among those with lower social class origins.

Yet, several studies from recent years have problematised the claim that social class does not influence the second generations' educational achievements. Research on the selectivity of immigrants suggests that social reproduction is highly relevant in understanding the mobility patterns among the second generation (Feliciano and Lanuza 2017; Lee and Zhou 2015). Broadening the conceptualisation of social class background, these studies consider the cultural resources that stem from pre-migration and illustrate that many immigrants have attained education and come from a middle-class background in their country of origin. Feliciano and Lanuza (2017) demonstrate that the most common intergenerational mobility pattern among the second generation is not upward mobility but class reproduction.

The class-related forms of resources obtained prior to migration can become important assets in the Norwegian educational system. In this study, we have included individuals with both working- and middle-class backgrounds. Building on the insights from the literature on social class, we explore the second generations' experiences with educational support and their 
sense of belonging in higher education. To specify the processes of belonging, we use the concept of frames.

\section{Frames of comparing educational achievement}

The scholarship on social class and second-generation mobility raises awareness of the cultural component of class reproduction. Culture and values matter for educational outcomes, but not in a static way. Culture works through frames - the lenses through which we observe and interpret social phenomena, such as achievement and success. Perceptions of possibilities and hindrances are relational; how well individuals think they are doing depends on their comparison with others and who these others are. Building on a Goffman framework, Lee and Zhou (2015) illustrate that although most immigrant parents and their children value education, the frame through which they define 'a good education' differs between different classes and ethnic groups. Furthermore, several contributions have illustrated how immigrants (the first generation) deploy a dual frame of reference - the host society and the home country, to situate the long-term costs and rewards of their migration lives (Louie 2012). By identifying the frames people adopt in their meaning and decision-making, this literature provide useful understandings of the variation between different groups' educational behaviour (Lee and Zhou 2015).

Following this line of reasoning, an important task is to explore the frames that the second generation deploy when they interpret their educational achievements and belonging in higher education. Do they deploy the host society's orientations, and compare themselves with the Norwegian majority population, or do they use their parents' home countries as a frame of reference when they evaluate and measure their educational outcomes? Louie (2006) illustrates that the American studies on the second generation give different answers to this question. Those studies that build on a segmented assimilation perspective suggest that the second generation uses a single frame of reference - the host society's frames - to understand their experiences in the segment of society in which they are assimilated (Portes and Rumbaut 2001). Children of immigrants can be either pessimistic or optimistic about their outcomes depending on how they fare in comparison with the majority population. Whereas studies that build on a transnational perspective suggest instead that the second generation also evaluates their lives in comparison with their parents' homeland (Louie 2012; Fernandez-Kelly 2008). Louie (2012) demonstrates how a dual frame of reference can have a symbolic meaning even when the second generation does not have actual transnational connections to the parents' homeland. Through the concept of the 'immigrant bargain', she captures how second-generation children feel the need to make up for their parents' sacrifices and hardships by achieving academic success. A key insight from the work exploring how immigrants and their children frame achievement and success is that the second generation might draw on multiple frames of references to make sense of their educational outcomes. In our study, we build on these insights when we analyse students' educational aspirations and belonging in higher education.

\section{Data and methods}

The quantitative data used for this article are taken from the StudData database. This is a repeated cross-sectional survey that covers students from 20 bachelor's programmes at 
11 universities in Norway. The data were collected during students' first year of study, and we pooled the observations from 2001, 2003 and 2012. The response rates were 74, 73 and $70 \%$, respectively.

The encouragement variable is based on the following question: 'To what extent have the following persons encouraged your choice of study?' (our translation): (a) mother, (b) father, (c) siblings, (d) friends and (e) others. The answers ranged from (5) 'to a very large extent' to (1) 'not at all'. We created a scale measurement that covers support from all sources, but we also regress its composing items to gauge each source of educational support. Ethnic minority and majority students are defined based on self-reports of country of birth and parents' country of birth.

We use OLS regression because this is a robust technique that is often used with Likert-type scales with five values. Dummy variables identify the cohorts from 2000 to 2003; the cohort from 2012 is the reference category. The control variables are parents' education levels (high school and vocational education (reference category), bachelor's degree, master's degree and missing information on education), gender $(\operatorname{men}=1)$, age $(>27$ years of age $=1)$ and study programme (social welfare, engineering, pedagogy, media, economy, police service and health science subjects (reference category)). ${ }^{1}$

Our qualitative data come from two studies in which young adults were interviewed about their aspirations, educational choices and experiences in the labour market. Study A follows students with ethnic minority and majority backgrounds from education to work. It consists of 66 in-depth interviews with 36 students and uses a two-stage design; we conducted interviews with the same individuals prior to their final exams and 1 year after graduating. Thirty of the thirty-six informants were interviewed twice. Semistructured interviews were used in both stages and lasted between 1 and $3 \mathrm{~h}$. The interviews focused on how the students experienced the curriculum, the student environment and their future possibilities as professionals. We recruited the informants by visiting lectures, seminars and mentoring meetings. The informants held a bachelor's degree from a university college. Fourteen of the thirty-six students have immigrant backgrounds, of whom six had themselves immigrated (from Iran, Iraq, Afghanistan and India) and eight (four men and four women) have parents who immigrated to Norway (from Pakistan, Sri Lanka, Lebanon, Turkey, Philippines and Bosnia). We focus on the experiences of the second generation in this article.

Study B is a small-scale study in which we interviewed eight women with ethnic minority backgrounds who attended a trainee programme. We recruited the informants directly through the leaders of the programme. The sample consisted of three women who immigrated to Norway themselves and five women whom have parents who immigrated. Again, the focus is on the second generation's experiences. In this informant group, four have parents who immigrated from South and West Asia, whilst one has parents from East Africa. Two of the second-generation informants have a master's degree from a university, and three hold a bachelor's degree from a university college. Both Studies A and B explore young adults' aspirations and perceptions of their labour market possibilities. Study B differs in that it only includes women with ethnic minority backgrounds. In sum, this article draws on interviews with 13 second-generation immigrants.

\footnotetext{
${ }^{1}$ The subjects that are particular to one or two cohorts are economics, in cohorts $\mathrm{A}$ and $\mathrm{C}$; policing, in cohort $\mathrm{C}$; and media and engineering, in cohorts $\mathrm{A}$ and $\mathrm{B}$. The regressions yield similar results when restricted to the subject areas present in all cohorts, i.e. health science, pedagogy and social work.
} 
In this article, students who originate from India, Iran, Pakistan and Vietnam dominate both the qualitative and quantitative sample. We do not attempt to make any substantial qualifications between those very different groups subsumed within the 'second-generation immigrant' category because our data do not provide a sufficiently large sample size for separate analyses based on national origin. This is not required for the investigations undertaken in this article because access to and the mobilisation of cultural resources are discussed with reference to minority ethnic groups generally (Modood 2004).

\section{Educational support}

Table 1 presents descriptive statistics on the dependent and independent variables across students with majority and minority backgrounds over the three cohorts. It clearly shows that most minority students have parents with low levels of education or lack information on their parents' levels of education. Whilst approximately half of majority students have parents with a bachelor's or master's degree, the corresponding fraction among minority students is onethird. The table reveals the female dominance among college professions because the percentage of women is $69 \%$ or higher.

We ran regressions on educational support in seven models. The first and second regressions presented in Table 2 investigate ethnic minorities' scores on the encouragement for educational support scale. The second to third to seventh regressions presented in the table investigate from whom students receive this support (parental support, sibling support, support from friends, support from others and support from other family members). In the last column, we show the results regarding support for fellow students (this variable is not part of the encouragement scale).

The first column shows the average level of encouragement received in total, summed across families, friends and other people. First-generation students from Asia report a level of encouragement higher to that of majority students, but the level of encouragement among second-generation students is comparable to that among majority ethnic students.

The second column repeats the analysis from column one, with the additional control for parents' highest level of education. Adjusting for parents' education level is relevant considering that ethnic minority students receive equal or higher levels of encouragement than their majority peers (c.f. Table 2, column 1) but have lower social origins (cf. Table 1). The analysis shows that students whose parents have tertiary education report receiving higher levels of support compared with those who have parents with secondary

Table 1 Parents' level of education

\begin{tabular}{llll}
\hline & Majority & 1st gen. & 2nd gen. \\
\hline $\begin{array}{l}\text { Encouragement } \\
\text { Independent variables (\%) }\end{array}$ & 2.84 & 3.05 & 2.95 \\
$\quad$ Men & 27 & 31 & 26 \\
$\quad$ Age & 18 & 49 & 5 \\
Parents' level of education (\%) & 16 & 10 & 4 \\
$\quad$ Master's degree & 34 & 28 & 25 \\
Bachelor's degree & 41 & 35 & 59 \\
High school & 9 & 27 & 12 \\
$\quad$ Missing & 7921 & 134 & 142 \\
Total $N$ & & & \\
\hline
\end{tabular}




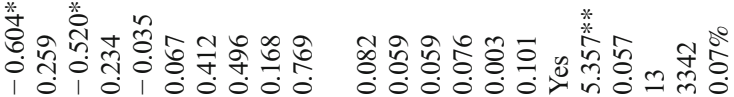

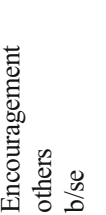

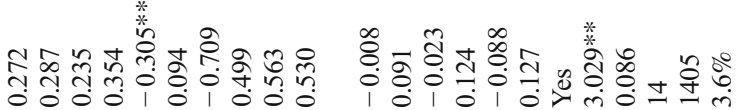

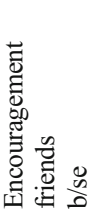

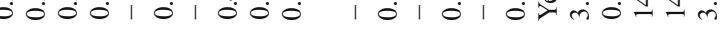



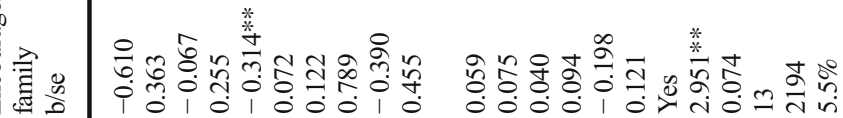

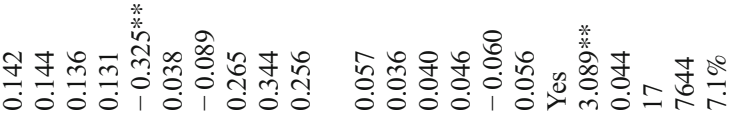


education, but introducing controls for parents' education level does not affect the coefficients for minority students' reported levels of encouragement. Moreover, interaction terms between parents' level of education and minority background are not statistically significant (results not shown), which implies that minority ethnic students from nonacademic families do not report higher levels of encouragement for their choice of study compared with majority ethnic students from similar social origins.

The results from column 3 show that parents generally provide high levels of encouragement in support of their offspring's choice of study. There are no statistically significant differences between the minority and majority groups, but second-generation men of Asian origin tend to receive higher levels of encouragement as compared with men with majority ethnic origin.

The fourth column reports the average levels of encouragement received from siblings. The levels of educational support elicited from siblings are lower than those elicited from parents. Nevertheless, first- and second-generation students of Asian origin report significantly higher levels of support from siblings as compared with their majority counterparts, and again, second-generation men of Asian origin have the highest scores, although the interaction term is insignificant. Hence, the observed difference can be due to chance.

The fifth column concerns support from the extended family. ${ }^{2}$ The levels of support received from other family members are higher among ethnic minority students as compared with ethnic majority students, but the differences are not statistically significant.

The figures in column 6 refer to encouragement from peers, and the average levels of support provided are generally high. There are no significant differences between minority and majority students.

The seventh column investigates support from others. ${ }^{3}$ In this context, others may imply extended family members and people in the community, excluding parents, siblings, friends, teachers, and college advisors. Minority students report a slightly higher level of support from 'others', but the coefficients are not statistically significant.

Column 8 reports the levels of support received from fellow students. This question is not part of the encouragement scale, but it is included because of its relevance to the topic under study. The results show that first- and second-generation students of Asian origin report significantly lower levels of support compared with the majority.

In sum, the survey data analysis shows that, on average, minority students enrolled in bachelor programmes at university colleges have parents with low levels of formal education. Nevertheless, first- and second-generation immigrants report receiving similar or higher levels of encouragement for their choice of study, primarily from siblings. Furthermore, students whose parents have some higher education report higher levels of encouragement for their choice of study compared with those students whose parents have secondary education. Yet, the data analysis does not support the hypothesis that minority students from lower social origins experience higher levels of encouragement in their choice of study compared with majority peers.

\section{Knowing One's academic place}

Students in higher education are members of a selective group who tend to be academically able and studious. However, social mobility through higher education is as much a process of

\footnotetext{
2 These questions were only asked in panel $\mathrm{C}$, hence the lower $N$.

${ }^{3}$ These questions were not asked in the 2003 panel, hence the lower $N$.
} 
learning the 'rules of the game' and how to fit in as it is a process of gaining knowledge, credentials or wealth (Lee and Kramer 2013). Several of the young students represented in our qualitative material come from working-class backgrounds. Do they suffer from the subtle exclusion that scholars have described as common among working-class students in higher education? By addressing how the students frame their educational attainment and aspirations, we explore their sense of belonging in higher education.

\section{Dual frame of reference}

The students emphasised their educational possibilities by comparing their situation with the poorer conditions in their parents' home countries and lives as first-generation immigrants in Norway. Parents' narratives of the family migration history or their encounters with the Norwegian society became important aspects of the informants' reflections on and legitimations of their own educational choices. This dual frame of reference influenced the students' interpretations and measures of educational success. They feel the need to accomplish higher education to make up for their parents' sacrifices. One of the male students with a workingclass background noted:

Neither of my parents have any education. In my entire family, there are only a few people who have an education. Still, for me, it's like... what they sacrificed to come to Norway. There was war, we escaped, and we did so much just to come here. I think it's like a personal pressure. If I don't get an education, I've wasted a great opportunity because I can see how people struggle over there. Our parents didn't have this opportunity. (Adil, Study A)

Both students with working-class and middle-class backgrounds use this dual frame of reference. They are trying to win what Louie (2012) has termed 'the immigrant bargain': educational success validates their parents migration decision and hardships in the host society. One of the students with middle class background notes:

Everyone in my family is educated. I think your family background plays a large role [in educational aspirations]. I can't see any reason for not taking a master's degree. Those who are born in Norway have great educational possibilities. They should take advantage of these possibilities. We who have backgrounds from places where there's poverty see this reality. We see that we have a unique opportunity. Our children will also have unique opportunities. Why not use them? You can't just hang around, wasting your life opportunities. My path to the future is open. I just have to walk it. [...] Our parents did not have this opportunity. Why should we waste it? I get so frustrated when I see those who just think about getting a job and quick money, such as driving a cab. That's what our parents did. They entered the labour market immediately because they didn't have a choice. (Khalid, Study A)

Although both middle- and working-class students deploy a dual frame of reference when they make sense of their educational attainment, there were some variations in the content of their references. Both informant groups shared stories of migration. However, the students with a middle-class background also shared stories about their family in classed terms. Typically, they described the position their parents, grandparents and broader family occupied in the class structure by naming their occupation, education or cast in the country of origin, thus describing 
a journey of downward mobility. In contrast, the students with a working-class background did not share similar classed family stories when they legitimated their aspirations and position in higher education. Thus, working- and middle-class parents might pass on different sorts of transnational narratives and memories to their children.

Several studies have demonstrated how parents' stories about their family's origin, ancestral country or migration story can become shared family narratives, fostering ambition in the second generation (Louie 2012; Fernandez-Kelly 2008). In this study, we also argue that the dual frame of reference provides a buffer against the exclusion and risks that scholars have described as common among working-class students in higher education. By deploying a dual frame of reference, the students describe their higher educational aspirations and their presence in higher education as something obvious and natural. Our qualitative analyses help to refine the quantitative findings. Even though the quantitative analysis showed equal levels of encouragement among second-generation immigrants, the qualitative interviews illustrate how the cultural ethos in immigrant families is about more than verbal support. Culture can be mobilised through frames of understanding educational attainment and success, strengthening minority students' aspirations and sense of belonging in higher education. Regardless of class, the dual frame of reference enables the students to feel entitled to an 'unfamiliar' field and view their place in academia as something natural and self-evident. Unlike the experiences of loss and sacrifice scholars have described as common among working-class students (Lee and Kramer 2013), we believe that the students' identification with shared narratives about their parents' migration stories, family origins and ancestral countries becomes an optimistic frame on mobility that can act as an important tool in achievement. It enables a type of self-understanding in which higher educational aspirations and attending higher education are experienced as almost given.

\section{Single frame of reference}

Although many of our interviewees came from families with relatively few financial and educational resources, several expressed a commitment to remaining in the education system. Both males and females experienced parental support and pressure regarding education and used a dual frame of reference when they made sense of their educational attainment. However, there are some gendered patterns in our interview data. Some female informants had experienced low educational support from their parents and felt constrained by teachers and advisors. When they reflected on their presence in higher education and their aspirations for the future, they did not use their parents' migration history to create a safe space of belonging in higher education. These female students interpret the constraints they encounter from their families or the majority society as gendered and ethnic constraints. They believe that their aspirations are opposed by others because they are minority women:

As minority women, it is often like, as one in my family told me, 'Why don't you just become a social worker? Look at the other girls. They've already got a house and a husband'. It's easy for me and girls who are like me to think that we just should do that. We don't have the role models. (...) I did well in school, worked hard and got good grades, but our parents constrained us. You don't have parents who motivate you. They protect you. (Sibel, Study B) 
Several of the female students experience low support for their aspirations and choice of higher education. Previous research demonstrates that second-generation females experience a female advantage in higher education. Second-generation women are overrepresented and perform remarkably well in higher education (Portes and Rumbaut 2001; Alba and Foner 2015) and are more likely to aspire to attain the highest-status occupations (Feliciano and Rumbaut 2005). Research has highlighted the intersecting pressures that ethnic minority women face in explaining the female advantage. Farris and de Jong (2013) illustrate how minority women play the role of 'bridges' between the family, the community and society as a whole. They describe how girls often feel that they must perform well and become a role model for the ethnic community to meet the families' expectations of mobility. However, the female educational advantage might not necessarily reflect strong educational support from the parental generation: it can also be a reflection of social control. Alba and Foner (2015, p. 188) point to the paradox that gender inequalities that tie girls to the home and reward female compliance may also produce academic success. Family responsibilities keep girls away from the temptations of the streets.

Another way to interpret the gendered pattern is to highlight the frames that the female students use to evaluate their educational choices and mobility. Their pessimistic perspective is embedded in a single frame of reference where they compare themselves with individuals with ethnic majority background in Norway. The comparison with the ethnic majority becomes evident when they reflect upon discrimination and constrained opportunities as minority women:

The entire society has oppressed us from primary school. I wanted to study general subjects in high school so that I could enter higher education, but the advisor said, 'You can't do that. As a Somali girl, it's better for you to become a social worker. Higher education isn't for you'. I had to go to him five times before he allowed me to choose the general subject. Norwegian parents would have supported me, but as an immigrant girl, I had to support myself. If I had a role model, I would have accomplished so much more today, someone who had believed in me and given me confidence. (Norah, Study B)

The female informants' narratives illustrate how crossing gendered, class or ethnic boundaries can be a risky and painful process. As second-generation immigrant women, they experience structural constraints due to their ethnic community, their parents and the majority society. However, regardless of their experiences with rejection, devaluation and discrimination, they entered higher education and displayed lofty aspirations regarding their future work lives. As one of the female students said during the interview: 'I have one goal. Within five years, I will have a top manager position'. The quote below also illustrates how the students continue to have strong drive and ambition despite their experiences with constraints and low support from others:

You have probably heard that all Pakistanis go to university, but for me, to be honest, I wish that my parents were more like that, that they had told me that education is important. My parents aren't illiterate, but they haven't got higher education either. I think that's why they didn't have this knowledge. They didn't realise that education was really important. (...) I remember when my older sister, who now studies medicine, wanted to go to high school. Several of my parents' friends had a really bad influence on my parents. They were like, 'Don't let her go to high school. Education isn't important' 
and stuff like that. So, my sisters and I had to make a choice. We were like, 'Do you know what - we will go to high school'. So she [my sister] finished high school (general studies) and started higher education. I remember that she told me that my parents were very concerned about her future and what she was going to do after finishing high school, whether she would get a job or a certificate of apprenticeship. If she had taken a vocational track, for example, medical secretary, she would go straight into a safe job. I think this has something to do with one's generation. They are very concerned about safety and that you have something to hold on to. (Faiza, Study A)

When the students present themselves as someone who refused to listen to their parents or teachers, they highlight their agency and bravery. Previous studies have described how the second-generation has learned to overcome experiences with exclusion and low support at a young age by choosing to work harder (Crul et al. 2017). Theoretical concepts such as resilience (Crul et al. 2017) point to the ability to recover from constraints, and it can be used by social agents to mobilise resources to attain specific goals. We believe that resilience is a process that is relevant in understanding success and aspirations among the female students in our sample. Yet, we believe that this is a behaviour that must be seen in relation to their single frame of reference, namely their experiences of being second-generation females in Norway. As suggested by the segmented assimilation perspective on second generation, individuals will employ the host society's orientation to understand their experience by comparing their outcomes with the natives in the segment where one is assimilated. When the informants compare themselves with the majority population and the Norwegian society, they anticipate that they will experience discrimination. However, their subjective experiences with discrimination do not lead to (self) exclusion but a pressure to work harder, prove that they will succeed, or do better in order to accomplish their educational aspirations. This may reflect the mechanism Puwar (2004) termed the 'burden of doubt'. In her work on racial exclusion in elite positions she argues that to combat under-expectations, racialised minorities have to prove themselves. She writes, 'Not only do these bodies that are out of place have to work harder to convince people that they are capable, but they also almost have to be crystal-clear perfect in their job performances, as any imperfections are easily picked up and amplified' (Puwar 2004, p. 61). In other words, high educational commitment and aspirations among the second generation might not necessarily reflect high levels of support but quite the contrary, the burden of doubt attached to minorities.

\section{Discussion and conclusion}

One influential strand of literature on second-generation educational attainment highlights the importance of cultural resources for minority students' aspirations and mobility (Modood 2004; Zhou 2005). The overarching story is that immigrants arrive in their destination countries already having a disposition towards achievement, which they pass on to their children by stressing educational attainment (Portes and Rumbaut 2001). This research helps explain how second-generation youth with working-class backgrounds develop high aspirations, learn and appropriate cultural resources and move up the social ladder. As Crul et al. (2017) argue, they are breaking the perpetual cycle of the habitus inherited through class position. What is less discussed and consequently less understood is whether and in what ways these cultural resources continue to act as resources in higher education. This study has 
investigated whether minority students report higher levels of support for their study choices compared with majority students and, secondly, how students convert cultural resources to achieve their higher education aims.

The quantitative findings showed that minority students do not receive a higher level of encouragement for their choice of study compared with majority students, except from siblings. This is commensurable with a previous study by Hermansen (2017), who found that older siblings motivated and supported younger siblings' educational choices. It also resonates with the interview data that showed sibling support to be an important resource for students. Levels of encouragement for children's educational choices from parents are generally high, irrespective of ethnic origin. However, the data show that social class matters for the level of encouragement received. Students whose parents have tertiary education generally report higher levels of encouragement for their choice of study than those whose parents have secondary education. This class-based measure of encouragement is more important than ethnic origin to explain variation in parental encouragement. Moreover, parental education level continues to explain variation in the levels of encouragement received from siblings, which indicates that academic families provide more supportive environments. Fekjær and Leirvik (2011) concluded that the differences regarding family relationships and educational success between Vietnamese and majority youth were smaller than expected. This study comes to a similar conclusion based on the quantitative data. Thus, the results of this analysis challenge the assumption that minority students receive extra support and encouragement from their social environment to guide them through higher education.

According to the literature on cultural resources, students who draw on 'ethnic capital' are socialised in a community that emphasises the value of higher education, and they have internalised the norms needed to accomplish this end (Basit 2012). In that case, support from others can be sufficient to maintain and reinforce study behaviour. The qualitative findings confirm this hypothesis. The interviews show how cultural resources can be mobilised through frames of interpreting and measuring educational success. We specified how culture works through two different frames of understanding educational achievement: a dual frame of reference and a single frame of reference.

First, the students deploy a dual frame of reference when they emphasise their educational possibilities by comparing their situation with the poorer conditions in their parents' home countries. Both students with working-class and middle-class backgrounds are trying to win what has been termed the immigrant bargain (Louie 2012). Their educational success validates their parents' migration decision and hardships in the host society. The dual frame of reference enables a self-understanding in which high educational aspirations and attending higher education are experienced as almost given. This finding has implications for scholarship on ethnic capital and retention in higher education. Support from home is crucial to academic completion. Our results illustrate how cultural resources are not only produced or converted via measurable outcomes (quantity and quality of support) but also through subtle forms of belongingness and students' sense of their place in higher education. Regarding identity, cultural resources may provide a buffer against the exclusion and risks scholars have described as common among working-class students in higher education (Lee and Kramer 2013). The students did not suffer from processes of selfexclusion but rather felt entitled to the field of higher education.

Second, in the qualitative material, we also illustrated how some of the female students used a single frame of reference, i.e. comparing their achievements with their peers with ethnic 
majority background in Norway, a frame that fostered pessimism. However, despite their experiences with discrimination and exclusion as minority women in the Norwegian society, the female informants entered higher education and displayed high aspirations for their future work life. We believe that this is a behaviour that reflects the mechanisms that have been termed the 'burden of doubt' (Puwar 2004), i.e. to combat under-expectation and discrimination ethnic minorities have to prove themselves by working harder.

Overall, this article demonstrates that in the field of higher education, cultural resources, which are defined as support and encouragement from the social environment, are not unequally distributed among ethnic minority and majority students. Both minority and majority students receive high levels of educational support, and classbased differences are more important than ethnicity to explain variation in encouragement. However, by exploring processes of meaning-making, this study illustrates how the members of the second generation, regardless of social class, use and mobilise cultural resources through multiple frames of success. Whilst the dual frame of reference enables the students to view their place in higher education as almost given and creates a sense of belonging, the single frame of reference enable the students to work harder in order to prove themselves and combat under-expectations. Future research should investigate in more detail the relationship between educational aspirations and career choices among minority youth and their experiences with constraints, such as social control and ethnic discrimination. The task in becoming more than what others have decided for you can be a painful and difficult process.

Acknowledgements We gratefully acknowledge the insightful comments of the anonymous reviewers and those of the research group Equality, inclusion and migration at Institute for Social Research, for valuable comments on an earlier draft of the article.

Funding This article is the result of the project 'Pathways to Integration: The Second Generation in Education and Work in Norway' (project nr. 10112) funded by the Research Council of Norway (RCN).

Open Access This article is distributed under the terms of the Creative Commons Attribution 4.0 International License (http://creativecommons.org/licenses/by/4.0/), which permits unrestricted use, distribution, and reproduction in any medium, provided you give appropriate credit to the original author(s) and the source, provide a link to the Creative Commons license, and indicate if changes were made.

\section{References}

Alba, R., \& Foner, N. (2015). Strangers no more immigration and the challenges of integration in North America and Western Europe. New Jersey: Princeton University Press.

Alba, R., \& Nee, V. (2003). Remaking the American mainstream: Assimilation and contemporary immigration. Cambridge: Harvard University Press.

Archer, L., \& Hutchings, M. (2000). Bettering yourself? Discourses of risk, cost and benefit in ethnically diverse, young working-class non-participants' constructions of higher education. British Journal of Sociology of Education, 21(4), 555-574. https://doi.org/10.1080/713655373.

Ball, S. J., Davies, J., David, M., \& Reay, D. (2002). 'Classification' and 'judgement': Social class and the 'cognitive structures' of choice of higher education. British Journal of Sociology of Education, 23(1), 51-72. https://doi.org/10.1080/01425690120102854.

Basit, T. N. (2012). 'My parents have stressed that since I was a kid': Young minority ethnic British citizens and the phenomenon of aspirational capital. Education, Citizenship and Social Justice, 7(2), 129-143. https://doi. org/10.1177/1746197912440857.

Blom, S., \& Henriksen, K. (2008). Levekår blant innvandrere i Norge 2005/2006 (2008/5). Oslo: Statistics Norway. 
Bourdieu, P. (1984). Distinction. A social critique of the judgement of taste. London: Routledge.

Bringsrud, S. F. (2014). Police students' social background, attitudes and career plans. Policing: an International Journal of Police Strategies \& Management, 37(3), 467-483. https://doi.org/10.1108 /PIJPSM-06-2011-0057.

Crul, M., Schneider, J., \& Lelie, F. (2012). The European second generation compared: Does the integration context matter? (European second generation compared). Amsterdam: Amsterdam University Press.

Crul, M., Schneider, J., Keskiner, E., \& Lelie, F. (2017). The multiplier effect: How the accumulation of cultural and social capital explains steep upward social mobility of children of low-educated immigrants. Ethnic and Racial Studies, 40(2), 321-338. https://doi.org/10.1080/01419870.2017.1245431.

Farris, S. R., \& de Jong, S. (2013). Discontinuous intersections: Second-generation immigrant girls in transition from school to work. Ethnic and Racial Studies, 37(9), 1505-1525. https://doi.org/10.1080 /01419870.2013.774033.

Fekjær, S. N. (2007). New differences, old explanations: Can educational differences between ethnic groups in Norway be explained by social background? Ethnicities, 7(3), 367-389. https://doi.org/10.1177 /1468796807080234.

Fekjær, S., \& Leirvik, M. (2011). Silent gratitude: Education among second-generation Vietnamese in Norway. Journal of Ethnic and Migration Studies, 37(1), 117-134. https://doi.org/10.1080/1369183 X.2011.521365.

Feliciano, C., \& Lanuza, Y. R. (2017). An immigrant paradox? Contextual attainment and intergenerational educational mobility. American Sociological Review, 82(1), 211-241. https://doi.org/10.1177 $/ 0003122416684777$.

Feliciano, C., \& Rumbaut, R. G. (2005). Gendered paths: Educational and occupational expectations and outcomes among adult children of immigrants. Ethnic and Racial Studies, 28(6), 1087-1118. https://oi. org/10.1080/01419870500224406.

Fernandez-Kelly, P. (2008). The back pocket map: Social class and cultural capital as transferable assets in the advancement of second-generation immigrants. The Annals of the American Academy of Political and Social Science, 620, 116-137. https://doi.org/10.1177/0002716208322580.

Goldthorpe, J. H. (2000). On sociology: Numbers, narratives, and the integration of research and theory. Oxford: Oxford University Press.

Heath, A. F., Rothon, C., \& Kilpi, E. (2008). The second generation in Western Europe: Education, unemployment, and occupational attainment. Annual Reviews, 34, 211-235.

Hermansen, A. S. (2016). Moving up or falling behind? Intergenerational socioeconomic transmission among children of immigrants in Norway. European Sociological Review, 32(5), 675-689. https://doi.org/10.1093/esr/jcw024.

Hermansen, A. S. (2017). Age at arrival and life chances among childhood immigrants. Demography, 54(1), 201-229. https://doi.org/10.1007/s13524-016-0535-1.

Ichou, M. (2014). Who they were there: Immigrants' educational selectivity and their children's educational attainment. European Sociological Review, 30(6), 750-765. https://doi.org/10.1093/esr/jcu071\%J.

Jetten, J., Iyer, A., Tsivrikos, D., \& Young, B. M. (2008). When is individual mobility costly? The role of economic and social identity factors. European Journal of Social Psychology, 38(5), 866-879. https://doi. org/10.1002/ejsp.471.

Lee, E. M., \& Kramer, R. (2013). Out with the old, in with the new? Habitus and social mobility at selective colleges. Sociology of Education, 86(1), 18-35. https://doi.org/10.1177/0038040712445519.

Lee, J., \& Zhou, M. (2015). The Asian American achievement paradox. New York: Russel Sage Foundation.

Louie, V. (2006). Second-generation pessimism and optimism: How Chinese and Dominicans understand education and mobility through ethnic and transnational orientations. International Migration Review, 40(3), 537-572. https://doi.org/10.1111/j.1747-7379.2006.00035.x.

Louie, V. (2012). Keeping the immigrant bargain: The costs and rewards of success in America. New York: Russell Sage Foundation.

Modood, T. (2004). Capitals, ethnic identity and educational qualifications. Cultural Trends, 13(2), 87-105.

Portes, A., \& Rumbaut, R. G. (2001). Legacies: The story of the immigrant second generation. Berkeley: University of California Press.

Puwar, N. (2004). Space invaders: Race, gender and bodies out of place. Oxford: Berg.

Reay, D. (2008). Psychosocial aspects of white middle-class identities: Desiring and defending against the class and ethnic 'other' in urban multi-ethnic schooling. Sociology, 42(6), 1072-1088.

Reay, D., Davies, J., David, M., \& Ball, S. J. (2001). Choices of degree or degrees of choice? Class, race and the higher education choice process. Sociology, 35(4), 855-874. https://doi.org/10.1017 /S0038038501008550. 
Shah, B., Dwyer, C., \& Modood, T. (2010). Explaining educational achievement and career aspirations among young British Pakistanis: Mobilizing 'ethnic capital'? Sociology, 44(6), 1109-1127. https://doi.org/10.1177 /0038038510381606.

Statistics Norway. (2017a). Innvandrere og norskfødte med innvandrerforeldre. 1.Januar 2017. https://www.ssb. no/befolkning/statistikker/innvbef/aar/2017-03-02.

Statistics Norway. (2017b). Lavere lønn blant innvandrere. 17. November 2017. https://www.ssb.no/arbeid-oglonn/artikler-ogpublikasjoner/lavere-lonn-blant-innvandrere.

Støren, L. A. (2009). Choice of study and persistence in higher education by immigrant background, gender and social background. Oslo: NifuStep.

Støren, L. A., \& Helland, H. (2010). Ethnicity differences in the completion rates of upper secondary education: How do the eEffects of gender and social background variables interplay? European Sociological Review, 26(5), 585-601. https://doi.org/10.1093/esr/jcp041.

Tjelmeland, H. (2003). Del I. 1940-1975. In K. Kjeldstadli (Ed.), Norsk innvandringshistorie 3: I globaliseringens tid 1940-2000. Oslo: Pax forlag.

Zhou, M. (2005). Ethnicity as social capital: Community-based institutions and embedded networks of social relations (ethnicity, social mobility and public policy: Comparing the USA and UK). New York: Cambridge University Press.

Publisher's note Springer Nature remains neutral with regard to jurisdictional claims in published maps and institutional affiliations. 